\title{
Evaluation OfProsopis Africana Seed Hydrolysates As Source Of Peptone For Microbial Culture Media
}

\author{
Onah, $\mathrm{AI}^{1}$, Okore, $\mathrm{VC}^{1}$, Tony Onah, $\mathrm{OF}^{2}$, ${ }^{*}$ Uronnachi, $\mathrm{EM}^{3}$ \\ ${ }^{1}$ Department OfPharmaceutics, Faculty Of Pharmaceutical Sciences, University Of Nigeria, Nsukka, Enugu \\ State, Nigeria. \\ ${ }^{2}$ Department OfNutrition And Dietetics, Faculty Of Agriculture, University Of Nigeria, Nsukka, Enugu \\ State, Nigeria. \\ ${ }^{3}$ Department OfPharmaceuticsAnd Pharmaceutical Technology, Faculty Of Pharmaceutical Sciences, \\ NnamdiAzikiwe University, Awka, Anambra State, Nigeria.
}

\begin{abstract}
Microbiological growth media developed from legumes as sources of protein hydrolysates was studied. This study was aimed at producing protein hydrolysates from Prosopis africana seed that could be used as a substitute to animal peptone for microbial culture. Prosopis africana seeds $(2.5 \mathrm{~kg})$ were obtained from a local market andselected seeds were washed with distilled water and boiled until the seed coats became soft. The softened seed coats were peeled off to obtain cotyledons which were washed, dried and powdered. The powdered cotyledon was subjected to enzymatic hydrolysis using papain, or acid hydrolysis using hydrochloric acid. Amino acid analysis was done using HPLC. Metal ion and vitamin contents of the hydrolysates were determined using standard methods. Growth patterns of Staphylococcus aureus, Pseudomonas aeruginosa, Escherichia coli, Candida albicans and Aspergillusniger in the media formulated using the seed hydrolysates were monitored. Microbial growth patterns in the hydrolysates were compared with commercial samples. The analyses revealed that papain-hydrolysed Prosopis africana seed (PHP) ranked highest in terms of microbial growth support when compared with acid-hydrolysed Prosopis africana seed (AHP) and commercial peptone $(C P)$. All the test organisms thrived well in media made with the hydrolysates, in comparison with commercially available media.
\end{abstract}

Keywords: Prosopis africana, hydrolysates, peptone, growth media

\section{Introduction}

Studies on the use of legumes as sources of protein hydrolysate for production of microbial growth media are limited. Regrettably, such potentials of these abundant indigenous plants have been neglected, apparently due to a lack of empirical data. In West Africa, as in the other parts of the world, legumes are of great economic and nutritional value. Prosopis africana is a leguminous plant with such high values[1]. However, studies available on the seeds of Prosopis africanawere limited to the microbial purity of seed hydrolysate. Bacillus species were isolated from the fermenting Prosopis africana cotyledons during the production of "okpeye", a food seasoning agent [2].The presence of a wide variety of bacterial species in the fermenting seeds is an indication that the seed hydrolysate could also be a source of protein (peptone) for microbial culture media. Microbial culture media are used for the purpose of isolating, studying and identification of microorganisms. In addition, culture media also provide a reliable means of estimating microbial growth as well as carrying out certain genetic manipulations in biotechnological advances. For a culture medium to be effective, it must contain all nutrients the microorganisms require for growth. The most important requirement of a culture medium is its ability to allow detectable growth from a minute inoculum within a reasonable period of incubation [3].By extension, the nutritional requirement that must be considered for microbial growth must provide sources of carbon, nitrogen and energy as well as other major mineral nutrients such as sulfur, phosphate, magnesium, calcium and trace elements [4].Peptones are protein hydrolysates that are soluble in water and are not heat coagulable [5].Most economical peptones are derived from products of bovine or porcine origin such as meat, internal organs, gelatin, and milk, as well as from certain plants and yeasts [6].Recent outbreaks of bovine spongiform encephalopathy and growing demand for raw materials that are approved and certified free of swine flu, have made peptones of non-meat origin to be increasingly important[7].Recent related researches[8] have established that peptones derived from soya beans and African locust beans supported the growth of the test organism and compared favourably well with commercial peptones. This shows that leguminous peptones contain the necessary nutrients required for microbial growth, especially the nitrogen requirement.

In view of these, it is now very pertinent that further studies and researches are carried out on more leguminous plants with the aim of exploring deeply to produce comparatively standard protein hydrolysates that can be used as alternative peptone for microbial culture in place of animal peptone. Production of alternative 
plant peptone will bring about much economic benefits in the commercialization of peptones. Exploration of leguminous plants as sources of protein hydrolysates will possibly reduce the cost of peptone for research and industrial uses. This study therefore aims at evaluating the protein hydrolysates obtained from the seeds of Prosopis africana, as an alternative source of peptone for the formation of microbial culture media.

\subsection{Materials}

\section{Materials And Methods}

The materials used for this study were Prosopis africana seeds bought from AhoMbu, Isi-Uzo Local Government Area of Enugu State and duly identified by Miss OgechiUgwuaneke of Crop Science Department, University of Nigeria, Nsukka, Nigeria. Peptone (Guangdong Huanki, China), Papain (BDH Chemicals Ltd, Poole, England), Hydrochloric acid (BDH Chemicals Ltd, Poole, England), Sabouraud dextrose agar (Lab M Limited, United Kingdom), mannitol-salt agar (Basingstoke Hampshire, England) and MacConkey agar (Titan Biotech Ltd, India), glucose, mannitol, sucrose and lactose (Kernel Chemicals Ltd, UK), maltose (Laboratory Technology Chemicals Co. Ltd, UK). The organisms used were: Pseudomonas aeruginosa, Bacillus subtilis, Escherichia coli, Staphylococcus aureus, Candida albicansandAspergillusniger. These were laboratory strains obtained from the Pharmaceutical Microbiology Department, University of Nigeria, Nsukka, Enugu State All other reagents and materials used were of analytical grade.

\subsection{Methods}

\subsubsection{Sample preparation}

Prosopis africanaseeds were purchased from a local market in Nigeria. The seeds were sorted to remove solid contaminants, and decaying seeds. The selected seeds were washed in de-ionized water and then boiled for 8 hours until the seed coats became soft and swollen. The seed coats were manually peeled off leaving behind the clean cotyledons. The cleaned cotyledons were dried in an oven at $40{ }^{\circ} \mathrm{C}$ for 12 hours, weighed and pulverized using a Kenwood blender (England). The resulting powder was kept in an air-tight container and stored at $4{ }^{\circ} \mathrm{C}$ prior to further procedures.

\subsubsection{Acid hydrolysis}

Two hundred grams of the Prosopis africana seed flour was soaked in $250 \mathrm{ml}$ of $6 \mathrm{M} \mathrm{HCl}$. The mixture was incubated at $80^{\circ} \mathrm{C}$ for 24 hours. At the end of the incubation period, the broth was diluted with $500 \mathrm{ml}$ of deionized water and then boiled at $100{ }^{\circ} \mathrm{C}$ for 1 hour. The solution was then cooled to room temperature, and the $\mathrm{pH}$ adjusted to 7.0 with $6 \mathrm{M} \mathrm{NaOH}$. The mixture was filtered through Whatman's No.1 filter paper. The filtrate was lyophilized using a freeze-dryer (Amsco/Finn-Aqua Lyovac GT3, Germany) to yield acid-hydrolysate of Prosopis africana seed (AHP).

\subsubsection{Papain hydrolysis}

Two hundred grams of powdered Prosopis africana seed was weighed and suspended in $800 \mathrm{ml}$ of distilled water. This was stirred to form slurry. The $\mathrm{pH}$ of the slurry was adjusted to 6.5 with $1 \mathrm{M} \mathrm{HCl}$. Papain (BDH Chemical Ltd, Pools, England), was added to the slurry to make a concentration of $0.25 \%$. Digestion was allowed to take place for $9 \mathrm{~h}$ at a temperature of $60{ }^{\circ} \mathrm{C}$, and the $\mathrm{pH}$ was controlled using $1 \mathrm{M} \mathrm{NaOH}$. The temperature was then raised to $80{ }^{\circ} \mathrm{C}$ for 15 minutes to inactivate the enzyme. Liquor from the hydrolysed material was separated from the protein/enzyme slurry by repeated centrifugation. The clear solution was then freeze-dried to obtain papain-hydrolysate of Prosopis africana seed (PHP).

\subsubsection{Determination of amino acids}

The analysis of the amino acids was done on Water 616 /626 LC (HPLC) instrument.

The sample preparation and determination were carried out in the following stages:

(i) Hydrolysis

(ii) Derivatisation

(iii) Separation of the derivatised amino acids

(iv) Data processing, interpretation and calculations of the final results

\section{Step (i) Hydrolysis of the samples:}

Five hundred milligram $(500 \mathrm{mg})$ of the sample was weighed into a sterile furnace hydrolysis tube. Five nmolsnorleucine was added to the sample and then dried under a vacuum. The tube was then again placed in a vial containing $10.05 \mathrm{~N} \mathrm{HCl}$ with a small quantity of phenol, thereby hydrolyzing the protein by the HClvapour under vacuum. This stage of hydrolysis of the sample lasted for between $20-23 \mathrm{~h}$ at $108{ }^{\circ} \mathrm{C}$. After the hydrolysis, the sample was dissolved in ultra-pure water (HPLC) grade, containing ethylene diamine tetra 
acetic acid (EDTA). The EDTA chelates the metal present in the samples. The hydrolysed samples now are stored in HPLC amino acid analyzer bottles for further analytical operations.

Step (ii): Derivatisation: The hydrolysed sample was derivatised automatically on the HPLC by reacting the amino acids, under appropriate condition, with phenylisothiocyanate (i.e. PITC) to get phenylthiocarbamyl (PTC) amino acid derivatives. The duration for this reaction is 45 minutes per sample, as calibrated on the instrument.

A set of standard solutions of the amino acids were prepared. These standards $(0.0,0.5,1.0,1.5,2.0$ $\mu \mathrm{mol})$ were used to generate a calibration file that was used to determine the amino acids contents of the samples. After the derivatisation, a methanol solution $(1.5 \mathrm{~N})$ containing the PTC-amino acid was transferred to a narrow bore in HPLC system for separation.

\section{Step (iii): The HPLC separation \& quantization}

The separation and quantitation of the PTC-amino acids were done on a reverse phase (18 silica column and the PTC chromophores were automatically and digitally detected at the wavelength of $254 \mathrm{~nm}$. The elution of the whole amino acids in the samples took $30 \mathrm{~min}$. The buffer system used for separation was $140 \mathrm{M}$ sodium acetate, $\mathrm{pH}$ 5.50, as buffer $\mathrm{A}$ and $80 \%$ acetonitrile as buffer B. The program was run using a gradient of buffer A and buffer B concentrations and ending with a $55 \%$ buffer B concentration at the end of the gradient.

\section{Step (iv): Data interpretation and calculations}

The intensity of the chromatographic peaks areas were automatically and digitally identified and quantified using a Dionexchromeleon data analysis system which is attached to the HPLC system.

The calibration curve or file prepared from the average values of the retention times (in minutes) and areas (in $\mathrm{mm}^{2}$ ) at the amino acids in 5 standards runs was used. For a known amount of each amino acid in the standard loaded into the HPLC, a response factor $\left(\mathrm{mm}^{2} / \mathrm{pmol}\right)$ was calculated by the software that was inter-phased with the HPLC. This response factor was used to calculate the amount of each of the amino acid (in pmols) in the sample and displayed on the system digitally. The amount of each amino acid in the sample is finally calculated by the software by dividing the intensity of the peak area of each (corrected for the differing molar absorptivity of the various amino acids) by the internal standard in the chromatogram and multiplying this by the total amount of internal standard added to the original sample. After the picomole of each amino acid has been ascertained by the software, the digital chromatographic software extrapolates back to the internal standard (Norleucine), and displays for the total amount that was pipetted into the hydrolysis tube at the beginning of the analysis.

\section{Calculation}

$\mathrm{mg} / \mathrm{ml}($ in extract $)=$ Dilution factor $\mathrm{x}$ Peak height intensity

$$
\mathrm{mg} / \mathrm{ml} \text { (in sample) }=\frac{\mu \mathrm{g} / \mathrm{ml} \text { in extract } \times \text { sample volume }}{\text { Weight of sample }}
$$

\subsubsection{Determination of vitamins \\ Determination of vitamin $B_{1}$ (Thiamine)}

Five gram of the sample was homogenized in $50 \mathrm{ml}$ ethanolic sodium hydroxide and filtered. Its $10 \mathrm{ml}$ filtrate was added to $10 \mathrm{ml}$ potassium dichromate and the absorbance was recorded at $360 \mathrm{~nm}$ in a spectrophotometer after the development of colour. The absorbance obtained from the sample extract was converted to thiamin concentration by means of calibration curve generated using standard concentrations [9].

$$
\text { Vitamin B1 content }=\frac{\text { Standard vitamin B1 }}{10 \mathrm{mg} / 100 \mathrm{~g}}-\frac{\text { Absorbance }}{0.025}
$$

\section{Determination of vitamin $\mathbf{B}_{2}$ (Riboflavin)}

Five grams of sample was extracted with $100 \mathrm{ml}$ of ethanol for $1 \mathrm{~h}$. To $10 \mathrm{ml}$ of the filtered extract was added $10 \mathrm{ml}$ of $5 \%$ potassium permanganate and $10 \mathrm{ml}$ of $3 \%$ hydrogen peroxide and it was allowed to stand on hot water bath for 30 minutes. To this was added $2 \mathrm{ml}$ of $40 \%$ sodium sulphate. The volume was made up to $50 \mathrm{ml}$ with distilled water. The sample was centrifuged at $1500 \mathrm{rpm}$ and the supernatant taken for spectrophotometric reading at $510 \mathrm{~nm}$. The absorbance obtained from the sample extract was converted to riboflavin concentration by means of calibration curve generated using different standard concentrations [9].

$$
\text { Vitamin B2 content }(\mathrm{mg} / 100 \mathrm{~g})=\frac{\text { Standard Vitamin B2 }}{10 \mathrm{mg} / 100 \mathrm{~g}}-\frac{\text { Absorbance }}{0.626}
$$




\section{Determination of vitamin $B_{3}$ (Niacin)}

Five grams of the sample was treated with $50 \mathrm{ml}$ of $1 \mathrm{M}$ sulphuric acid for 30 minutes. Then $0.5 \mathrm{ml}$ ammonia solution was added to it and then filtered. To $10 \mathrm{ml}$ of the filtrate was added $5 \mathrm{ml}$ of $0.5 \%$ potassium cyanide. This was further acidified with $5 \mathrm{ml}$ of $0.02 \mathrm{M}$ sulphuric acid. The absorbance of the resultant solution was recorded at $420 \mathrm{~nm}$. The absorbance obtained from the sample extract was converted to niacin concentration by means of a calibration curve generated using different standard concentrations [9].

$$
\text { Vitamin B3 content }(\mathrm{mg} / 100 \mathrm{~g})=\frac{\text { Standard Vitamin B3 }}{3.23 \mathrm{mg} / 100 \mathrm{~g}}-\frac{\text { Absorbance }}{0.090}
$$

\section{Determination of vitamin $B_{6}$ (Pyridoxine)}

One gram of the sample was weighed separately into a $100 \mathrm{ml}$ conical flask and extracted with $10 \mathrm{ml}$ of $0.1 \mathrm{M} \mathrm{HCl}$ with vigorous shaking for 10 minutes. The sample was filtered through Whatman's No. 1 filter paper. The filtrate was then made up to $10 \mathrm{ml}$ with distilled water. Five milliliters of the slightly acidic filtrate is treated with $1 \mathrm{ml}$ of $0.04 \%$ ferric chloride. The optical density of the resultant brown solution was measured in a spectrophotometer at $450 \mathrm{~nm}$. The absorbance obtained from the sample extract was converted to pyridoxine concentration by means of a calibration curve generated using different standard concentrations [9].

$$
\text { Vitamin B6 content }(\mathrm{mg} / 100 \mathrm{~g})=\frac{\text { Standard Vitamin B6 }}{0.25 \mathrm{mg} / 100 \mathrm{~g}}-\frac{\text { Absorbance }}{0.05}
$$

\section{Determination of vitamin $B_{12}$ (Cyanocobalamin)}

One gram of the sample was weighed into a flat-bottom flask and $50 \mathrm{ml}$ of $0.1 \mathrm{M} \mathrm{HCl}$ was added to it. The flask was thoroughly swirled and allowed to stand for $2 \mathrm{~h}$. The mixture was then filtered and $10 \mathrm{ml}$ aliquot taken in a test tube for spectrophotometric reading. A volume of $0.5 \mathrm{ml}$ of $0.2 \%$ ferric chloride in ethanol and $0.5 \mathrm{ml}$ of $0.5 \%$ alpha-alpha dipyridyl were added to the sample in the presence of acetate buffer $(5 \mathrm{ml})$ which was read within 10 minutes in a spectrophotometer at $550 \mathrm{~nm}$ [10].

$$
\text { Vitamin B12 content }(\mathrm{mg} / 100 \mathrm{~g})=\frac{\text { Standard Vitamin B6 }}{50 \mathrm{mg} / 100 \mathrm{~g}}-\frac{\text { Absorbance }}{0.108}
$$

\section{Determination of vitamin C (Ascorbic acid)}

Five grams of the sample was weighed into a flat-bottom flask and $60 \mathrm{ml}$ TCA/acetic acid solution was added. The mixture was left for about an hour before it was filtered. The filtrate was made up to $200 \mathrm{ml}$ with distilled water. A volume of $10 \mathrm{ml}$ was taken for titration with $0.005 \%$ of 2, 6-dichlorophenols [11]. The vitamin $\mathrm{C}$ content was calculated as follows:

$\mathrm{K}=\frac{\mathrm{Y} \times \mathrm{Z} \times \mathrm{DF}}{\text { Weight of sample }(\mathrm{g})}$

where $\mathrm{Y}=$ Titre value; $\mathrm{Z}$ is the figure obtained when $50 \mathrm{~g}$ of the standard vitamin $\mathrm{C}$ is divided by its titre value, and DF: Dilution factor.

\section{Determination of vitamin A}

One gram of the sample was weighed. Then the proteins in the weighed sample were first precipitated with $3 \mathrm{ml}$ of absolute ethanol before the extraction of vitamin A with $5 \mathrm{ml}$ of heptane. The test tube containing this was shaken vigorously for 5 minutes. On standing, $3 \mathrm{ml}$ from the heptane layer was taken up in a cuvette and read at $450 \mathrm{~nm}$ against a blank of heptane. The standard was prepared following same procedure, and read at $450 \mathrm{~nm}$ [12].

\section{Determination of Vitamin E (Tocophenrol)}

One gram $(1 \mathrm{~g})$ of the sample was extracted with $50 \mathrm{ml}$ of petroleum ether and evaporated to dryness. The residue was saponified with $5 \mathrm{ml}$ of $0.1 \mathrm{M}$ potassium hydroxide under reflux. Twenty milliliters $(20 \mathrm{ml})$ of petroleum ether was used to extract the unsaponifiable matter and evaporated to dryness. Twenty milliliters $(20$ $\mathrm{ml})$ of ethanol was added to dissolve the residue. One milliliter $(1 \mathrm{ml})$ was transferred into 3 separate test tubes to which was added $1 \mathrm{ml}$ of $0.2 \%$ ferric chloride in ethanol and $1 \mathrm{ml}$ of $0.5 \% \alpha$-dipyridyl and was made up to 5 $\mathrm{ml}$ with ethanol. The absorbance was taken at $520 \mathrm{~nm}$ wavelength [9].

Calculation:\% Vitamin $\mathrm{E}=\frac{\text { Absorbance of test } \times \text { concentration of standard } \times \mathrm{DF}}{\text { Absorbance of standard } \times \text { Weig ht of sample }(\mathrm{g})} \times \frac{100}{1}$

\subsubsection{Determination of metals Calcium}


Five grams of sample was dissolved in $100 \mathrm{ml}$ of distilled water. Ten milliliters $(10 \mathrm{ml})$ of the sample solution was pipetted into a $250 \mathrm{ml}$ of $0.5 \mathrm{M} \mathrm{KOH}$ in a conical flask and $25 \mathrm{ml}$ of water was added and finally a pinch of calcine indicator was added. The mixture was titrated against $0.1 \mathrm{M}$ EDTA solution to an end point. The volume of the EDTA is equivalent to volume of calcium in the solution [13].

Calculation:

$$
\% \text { Calcium }=\frac{\text { Vol. EDTA } \times \text { Mol.EDTA } \times \text { Atomic weight of Ca } \times 100 \times \mathrm{DF}}{1000 \times \text { Weight of sample }}
$$

\section{Magnesium}

The sample solution was prepared by dissolving $5 \mathrm{~g}$ of samples each (PAH and CP) in $100 \mathrm{ml}$ of distilled water. Ten milliliters $(10 \mathrm{ml})$ of the sample solution was pipetted into a $250 \mathrm{ml}$ conical flask. About 25 $\mathrm{ml}$ of $\mathrm{NH}_{3}-\mathrm{NH}_{4}$ buffer solution at the $\mathrm{pH}$ of 7.2 was added to it. Twenty-five millilitres ( $25 \mathrm{ml}$ ) of water was added to the mixture followed by 2-3 drops of Eriochrome Black T indicator and titrated against 0.1 M EDTA solutions. The volume of EDTA used was the volume equivalent of magnesium in the mixture [14].

The volume of magnesium $=($ Volume of Calcium and Magnesium - Volume of Calcium $)$

$$
\% \mathrm{Mg}=\frac{\text { Vol. EDTA } \times \text { Mol. EDTA } \times \text { Atomic weight of Mg } \times \mathrm{DF}}{1000 \times \text { Weight of sample }(\mathrm{g})} \times \frac{100}{1}
$$

where $\mathrm{DF}=$ Dilution factor

\section{Iron and Zinc}

Two milligrams of the sample was weighed into a crucible and ashed in a muffle furnace at $555{ }^{\circ} \mathrm{C}$ for 6 hours. The ash was cooled and $6 \mathrm{ml}$ of $1 \mathrm{M} \mathrm{HCl}$ added and boiled for $10 \mathrm{~min}$, while covering the crucible with a watch glass. After boiling, the sample was cooled and filtered into $100 \mathrm{ml}$ volumetric flask. The crucible was washed with distilled water and ash filtrate was added. The ash filtrate was made up to $100 \mathrm{ml}$ with distilled water. An aliquot of the filtrate was aspirated into atomic absorption spectrophotometer (PYE UNICAM, England) and the absorbance values of the different minerals read. Standard solutions of iron and zinc were prepared and aspirated into the atomic absorption spectrophotometer and their absorbance values were recorded. The percentage of element present was calculated from the absorbance values of the samples and standard solutions [14].

\section{Copper}

This was determined using [14] method. One gram of the sample was weighed into a digestion flask and $20 \mathrm{ml}$ of acid mixture $\left(650 \mathrm{ml}\right.$ conc. $\mathrm{HNO}_{3} ; 80 \mathrm{ml}$ of perchloric acid (PCA); $20 \mathrm{ml}$ conc. $\left.\mathrm{H}_{2} \mathrm{SO}_{4}\right)$ was added. The flask was heated until a clear digest was obtained. The digest was diluted with distilled water to $500 \mathrm{ml}$ mark. A stock solution of $100 \mathrm{mg} / \mathrm{ml}$ of $\mathrm{Cu}^{2+}$ ions was prepared by dissolving $2.682 \mathrm{~g} \mathrm{of} \mathrm{CuCl}_{2} .2 \mathrm{H}_{2} \mathrm{O}$ in deionized water and finally diluted to $1000 \mathrm{ml}$. Standard concentration of $0.5 \mathrm{ppm}$ was prepared from this stock solution and absorbance was taken at $360 \mathrm{~nm}$.

\section{Sodium and potassium}

Two grams ( $2 \mathrm{~g})$ of the sample was weighed into a digestion flask and $20 \mathrm{ml}$ of acid mixture $(650 \mathrm{ml}$ of conc. $\mathrm{HNO}_{3}, 80 \mathrm{ml} \mathrm{PCA}$, and $20 \mathrm{ml}$ conc. $\mathrm{H}_{2} \mathrm{SO}_{4}$ ) was added. The flask was heated until a clear digest was obtained. The digest was diluted with distilled water to $500 \mathrm{ml}$. An aliquot of the sample digest was taken for photometry using Flame analyzer. Absorbance for sodium was read at $767 \mathrm{~nm}$ while that of potassium was read at $589 \mathrm{~nm}$. Sodium and potassium concentrations are obtained from the calibration curves obtained from the standard [14].

Calculation:

$\mathrm{Ppm}=\frac{\mathrm{Gf} \times \text { Total volume of extract } \times \mathrm{Ab} \times \mathrm{DF}}{\text { Weight of sample }(\mathrm{g})}$

where $\mathrm{DF}=$ Dilution factor; $\mathrm{Gf}=$ Gram factor, and $\mathrm{Ab}=$ Absorbance.

\section{Manganese}

A volume of $2 \mathrm{ml}$ of phosphoric acid was added to $2 \mathrm{ml}$ of the sample (prepared by dissolving $2 \mathrm{~g}$ of sample in $50 \mathrm{ml}$ of distilled water). Appropriate amount of $0.3 \mathrm{~g}$ potassium periodate was added and the beaker was covered with a watch glass. The solution was boiled on a hot plate and simmered gently for 5 minutes. The beaker was allowed to stand on a boiling water bath for 30 minutes. The solution was allowed to cool and transferred to a $50 \mathrm{ml}$ graduated flask and diluted to $50 \mathrm{ml}$. The reading of the absorbance was taken at $525 \mathrm{~nm}$ [9]. 


\section{Mercury}

This was determined using titrimetric method. Two grams of the sample was digested by wet-ashing with perchloric acid and nitric acid in the volume of $6: 3$ and made up to $100 \mathrm{ml}$ with distilled water. Twenty five milliliters aliquot was measured into a conical flask and $2 \mathrm{ml}$ of dithizone was added. This was acidified by adding $10 \mathrm{ml}$ of acidified sodium nitrite. The solution was titrated with $0.001 \mathrm{M}$ dithizone solution. Titration continued until colour change occurred.

Calculation

Mercury $=\frac{\mathrm{T} \times \text { concentration } \times \mathrm{TV} \times 96}{\text { Weight of sample } \times \text { aliquot }} \times \frac{100}{1}$

where T: Titre value; TV: Total volume obtained after wet-ashing, and Concentration: Concentration of dithizone solution used for titration.

\subsubsection{Microbial growth evaluation}

Microbial growth media were formulated using either commercially available peptone $(1 \%)$ or peptone hydrolysates from Prosopis africana seed (1\%). The pH range of the peptone hydrolysate media was 6.8 to 7.2. The solutions were dispensed as $50 \mathrm{ml}$ aliquots into a $250 \mathrm{ml}$ Erlenmayer flask and autoclaved at $121{ }^{\circ} \mathrm{C}$ for 15 minutes. A volume of $9.9 \mathrm{ml}$ of each formulated medium was distributed into five test tubes in which the different test organisms were placed. An inoculum of $0.1 \mathrm{ml}$ of $10^{5}$ colony forming units $(0.5 \mathrm{McFarland}$ 's standard) of each test organism was introduced into the test tubes and the culture was incubated at $30{ }^{\circ} \mathrm{C}$ on a rotary shaker $(150 \mathrm{rpm})$ for 24 hours. The absorbance of the biomass was recorded at $650 \mathrm{~nm}$ using a spectrophotometer (Model 752, China). These procedures were repeated for varied PAH and CP concentration of 2, 3, 4 and $5 \mathrm{mg} \%$ respectively. For solid media, the molten agar media containing the seed hydrolysate or commercial peptone were also added to five separate petri dishes. The contents were thoroughly mixed and allowed to solidify. An inoculum of $0.1 \mathrm{ml}$ of $10^{5}$ colony forming units of each test organism was streaked on the media, and incubated at $37{ }^{\circ} \mathrm{C}$ for 24 hours for bacteria and $25{ }^{\circ} \mathrm{C}$ for 72 hours for the fungi.

\subsection{Statistical analyses}

Mean and standard deviations were calculated for the result generated using Microsoft excel 2013.

\subsection{Yield of the hydrolysate}

\section{Results}

For AHP, the weight of the freeze-dried sample was $104 \mathrm{~g}$ and the percentage yield was $52 \%$.

For PHP, the weight of the lyophilized hydrolysate was $132 \mathrm{~g}$ and its percentage yield was $66 \%$.

Table 1: Amino acid composition of PHP, AHP and CP

\begin{tabular}{llll}
\hline & PHP $(\%)$ & $\begin{array}{l}\text { Media } \\
\text { AHP }(\%)\end{array}$ & CP $(\%)$ \\
\hline Essential amino acids & & & \\
Arginine & $0.229 \pm 0.02$ & $0.236 \pm 0.01$ & $0.903 \pm 0.01$ \\
Histidine & $0.393 \pm 0.03$ & $0.406 \pm 0.03$ & $1.551 \pm 0.002$ \\
Leucine & $0.354 \pm 0.001$ & $0.262 \pm 0.01$ & $0.735 \pm 0.02$ \\
Isoleucine & $1.607 \pm 0.002$ & $0.450 \pm 0.03$ & $1.262 \pm 0.01$ \\
Lysine & $2.632 \pm 0.02$ & $1.948 \pm 0.01$ & $5.470 \pm 0.01$ \\
Methionine & $0.912 \pm 0.01$ & $0.075 \pm 0.03$ & $1.210 \pm 0.03$ \\
Phenylalanine & $0.914 \pm 0.03$ & $0.158 \pm 0.01$ & $0.744 \pm 0.004$ \\
Threonine & $3.354 \pm 0.004$ & $0.262 \pm 0.01$ & $7.735 \pm 0.03$ \\
Tryptophan & $0.165 \pm 0.01$ & $0.218 \pm 0.03$ & $0.647 \pm 0.01$ \\
Valine & $0.529 \pm 0.01$ & $0.236 \pm 0.001$ & $0.903 \pm 0.01$ \\
Non-essential amino & & & \\
acids & & & \\
Alanine & $1.703 \pm 0.02$ & $1.758 \pm 0.01$ & $6.719 \pm 0.002$ \\
Aspartic acid & $0.066 \pm 0.01$ & $0.068 \pm 0.02$ & $2.258 \pm 0.02$ \\
Asparagine & $2.138 \pm 0.001$ & $0.143 \pm 0.04$ & $1.545 \pm 0.01$ \\
Glutamic acid & $0.102 \pm 0.002$ & $0.106 \pm 0.003$ & $0.430 \pm 0.03$ \\
Glutamine & $0.576 \pm 0.003$ & $0.763 \pm 0.001$ & $0.514 \pm 0.02$ \\
Glycine & $0.576 \pm 0.01$ & $0.763 \pm 0.01$ & $5.514 \pm 0.003$ \\
Proline & $0.990 \pm 0.03$ & $1.311 \pm 0.005$ & $0.883 \pm 0.02$ \\
Serine & $4.289 \pm 0.01$ & $5.679 \pm 0.02$ & $3.827 \pm 0.05$ \\
Tyrosine & $0.158 \pm 0.05$ & $0.177 \pm 0.03$ & $1.328 \pm 0.01$ \\
\hline
\end{tabular}




\begin{tabular}{llll}
\hline Cystine & $0.348 \pm 0.01$ & $0.461 \pm 0.05$ & $0.311 \pm 0.001$ \\
\hline
\end{tabular}

PHP:PapainhydrolysedProsopis africana seed, AHP: AcidhydrolysedProsopis africana seed, CP: Commercial peptone

Table 2: Vitamin compositions of PHP, AHP and CP

\begin{tabular}{llll}
\hline Vitamins & PHP & AHP & CP \\
\hline Vitamin B1 $(\mathrm{mg} / 100 \mathrm{~g})$ & $8.00 \pm 0.02$ & $0.182 \pm 0.02$ & $4.44 \pm 0.01$ \\
Vitamin B2 $(\mathrm{mg} / 100 \mathrm{~g})$ & $0.684 \pm 0.01$ & $0.023 \pm 0.02$ & $1.04 \pm 0.01$ \\
Vitamin B3 (mg/100 g) & $9.556 \pm 0.01$ & $0.405 \pm 0.03$ & $7.46 \pm 0.02$ \\
Vitamin B6 (mg/100 g & $1.367 \pm 0.02$ & $0.088 \pm 0.01$ & $1.06 \pm 0.01$ \\
Vitamin B12 (mg/100 g) & $0.616 \pm 0.03$ & $0.094 \pm 0.01$ & $0.146 \pm 0.02$ \\
Vitamin C (\%) & $2.20 \pm 0.01$ & $0.802 \pm 0.01$ & $=$ \\
Vitamin A (IU/100 g) & $70.922 \pm 0.02$ & $7.751 \pm 0.01$ & $0.08 \pm 0.03$ \\
Vitamin E (mg/100 g) & $0.86 \pm 0.05$ & $0.37 \pm 0.03$ & $0.11 \pm 0.01$ \\
\hline
\end{tabular}

PHP:PapainhydrolysedProsopis africana seed, AHP: AcidhydrolysedProsopis africana seed, CP: Commercial peptone

Table 3: Metal ions composition of PHP, AHP and CP

\begin{tabular}{llll}
\hline Minerals (mg/100g) & PHP & Media \\
AHP & CP \\
\hline Calcium & $10.15 \pm 0.003$ & $4.239 \pm 0.02$ & $68.80 \pm 0.01$ \\
Magnesium & $26.05 \pm 0.001$ & $3.186 \pm 0.03$ & $32.64 \pm 0.004$ \\
Zinc & $2.31 \pm 0.04$ & $1.783 \pm 0.01$ & $1.70 \pm 0.006$ \\
Iron & $4.38 \pm 0.01$ & $5.140 \pm 0.02$ & $5.25 \pm 0.007$ \\
Copper & $5.01 \pm 0.02$ & $2.416 \pm 0.003$ & $0.11 \pm 0.10$ \\
Potassium & $48.17 \pm 0.01$ & $36.423 \pm 0.002$ & $16.00 \pm 0.05$ \\
Sodium & $31.64 \pm 0.04$ & $28.598 \pm 0.01$ & $18.42 \pm 0.03$ \\
Manganese & $2.03 \pm 0.02$ & $1.371 \pm 0.003$ & $2.11 \pm .0 .03$ \\
Mercury & $0.42 \pm 0.03$ & $0.607 \pm 0.002$ & $0.12 \pm 0.01$ \\
\hline
\end{tabular}

PHP:PapainhydrolysedProsopis africana seed

AHP:AcidhydrolysedProsopis africana seed

CP:Commercial peptone

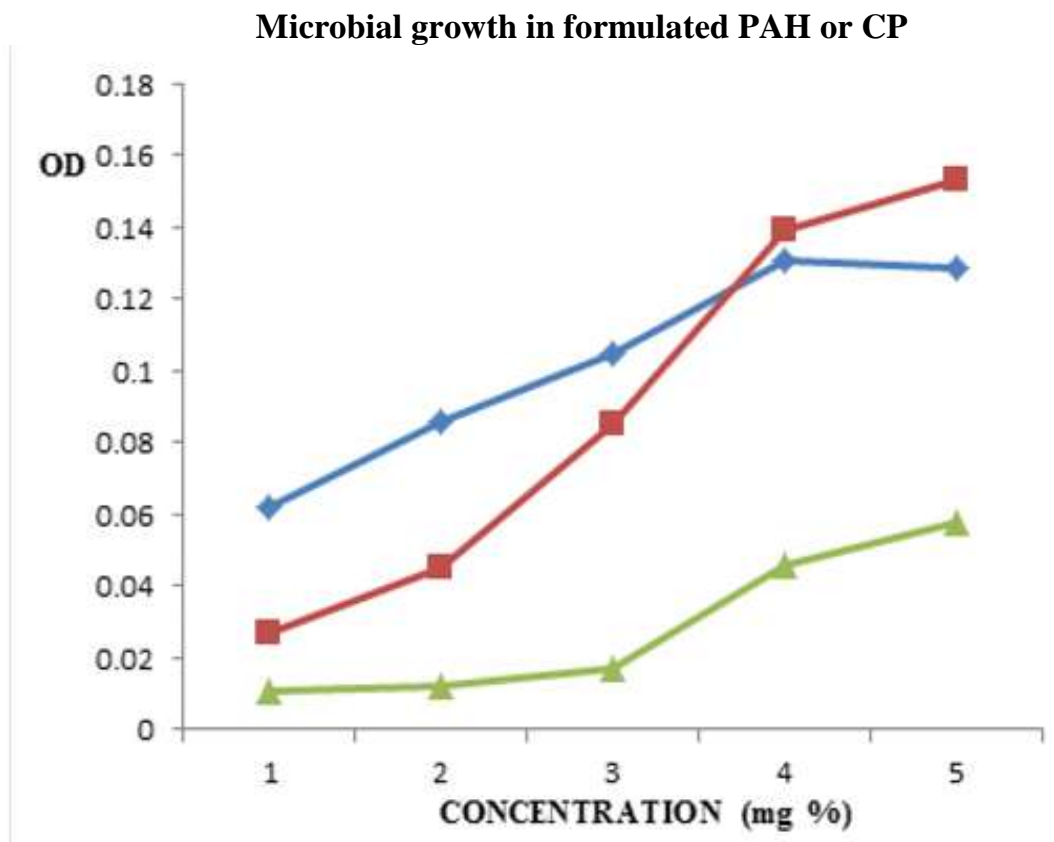

Fig. 1: Growth of Staphylococcus aureus in PAH and CP at 24 hours of incubation

Key:

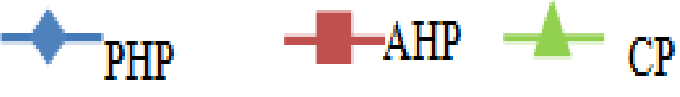




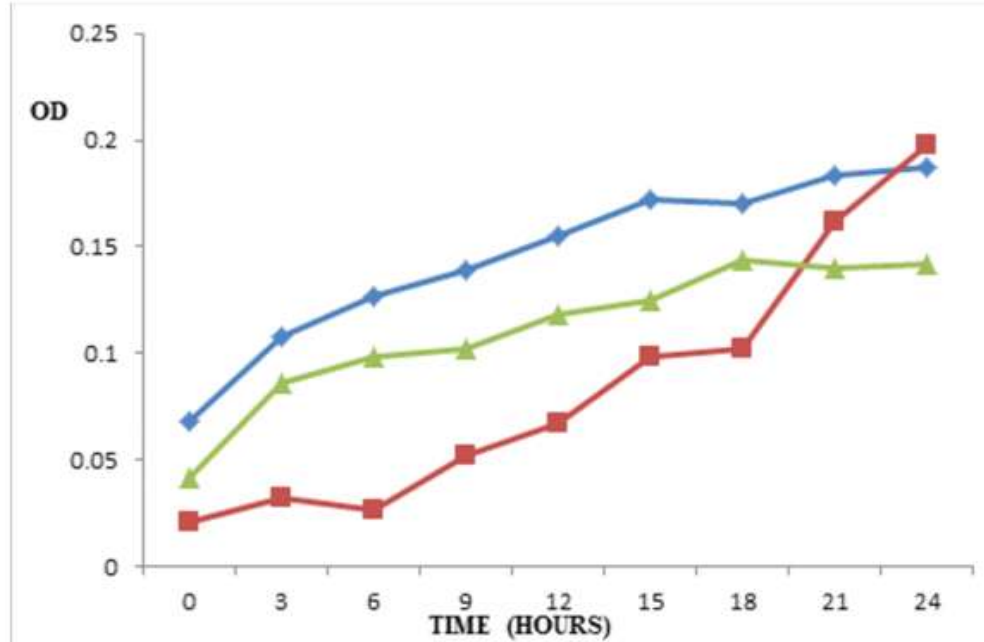

Fig. 2: Growth curve of Staphylococcus aureus in $4 \mathrm{mg} \%$ concentration of PHP, AHP or

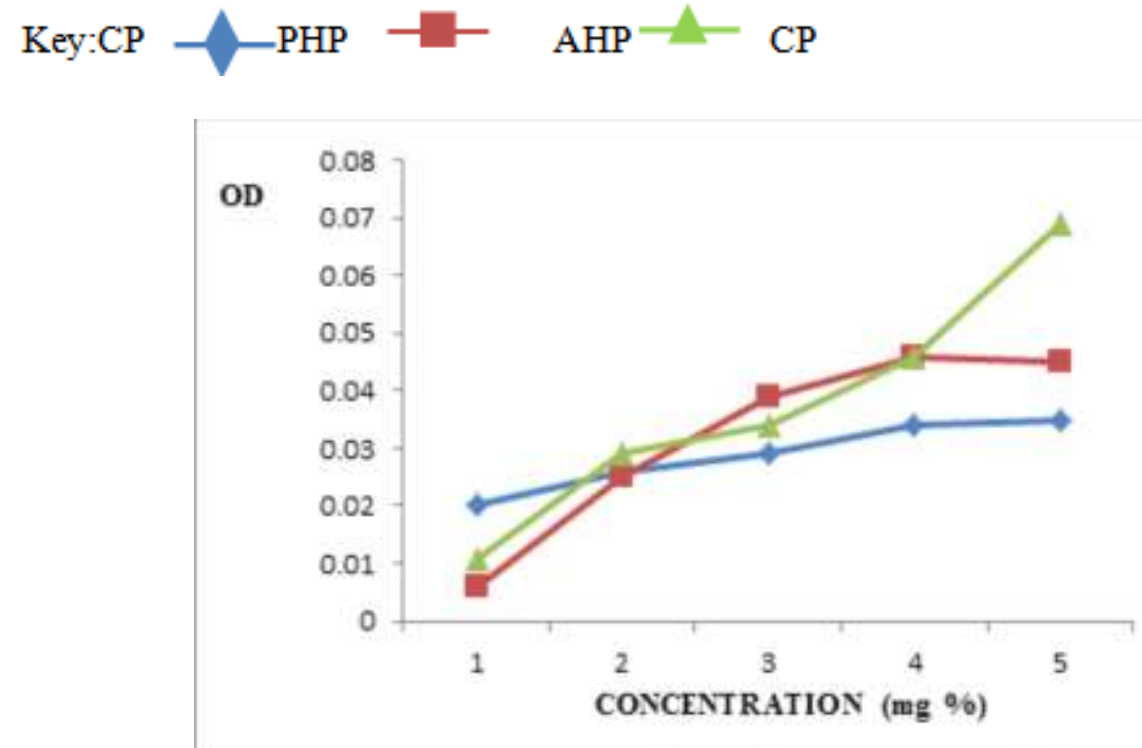

Fig. 3: Growth of Escherichia coli in PAH and CP at 24 hours of incubation

Key: $\longrightarrow$ PHP $\longrightarrow$ AHP $\longrightarrow$ CP

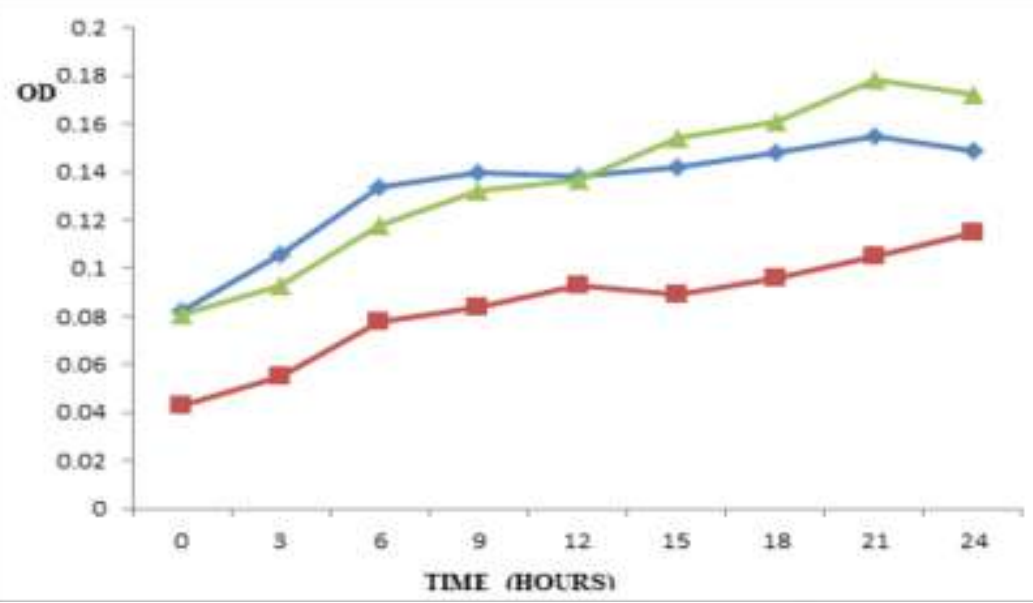
$\mathrm{CP}$

Fig. 4: Growth curve of Escherichia coliin $4 \mathrm{mg} \%$ concentration of PHP, AHP or

Key:

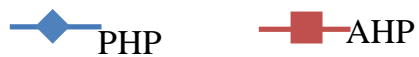

$-\mathrm{CP}$ 


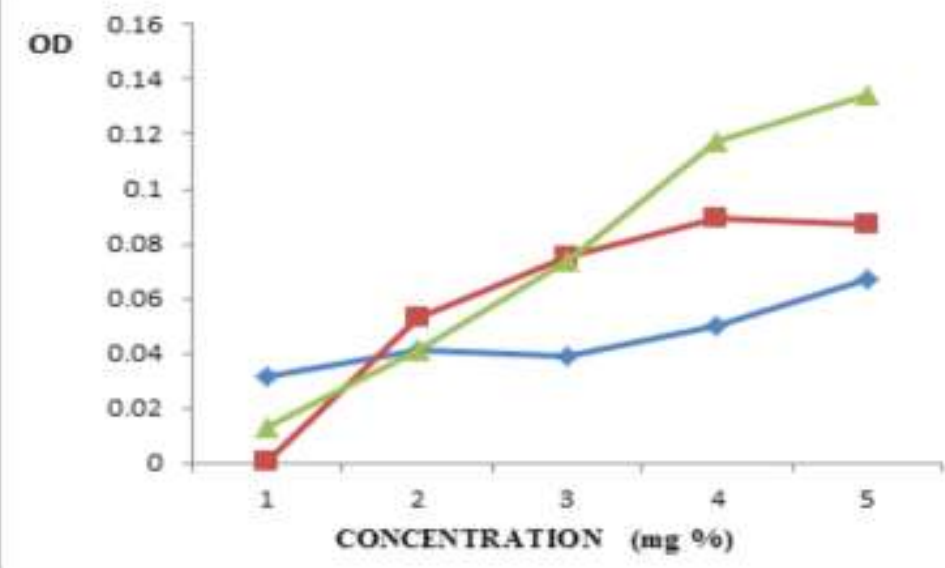

incubation

Fig. 5: Growth curve of Pseudomonas aeruginosa in $\mathrm{PAH}$ and $\mathrm{CP}$ at 24 hours of

Key:
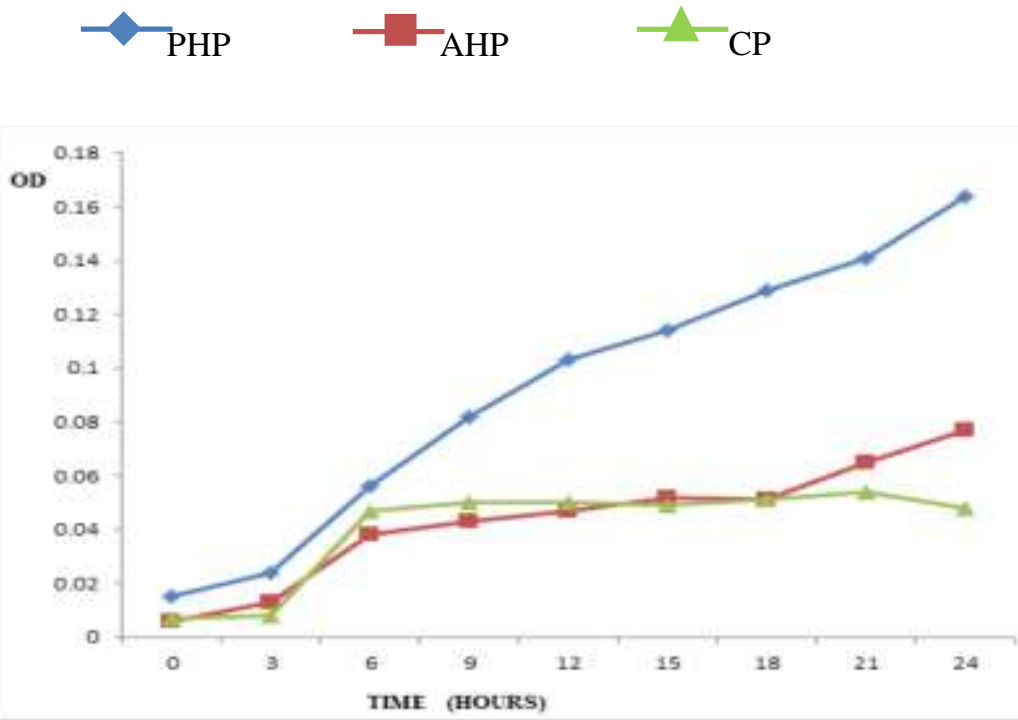

AHP or CP

Fig. 6: Growth curve of Pseudomonas aeruginosain $4 \mathrm{mg} \%$ concentration of PHP,

Key:
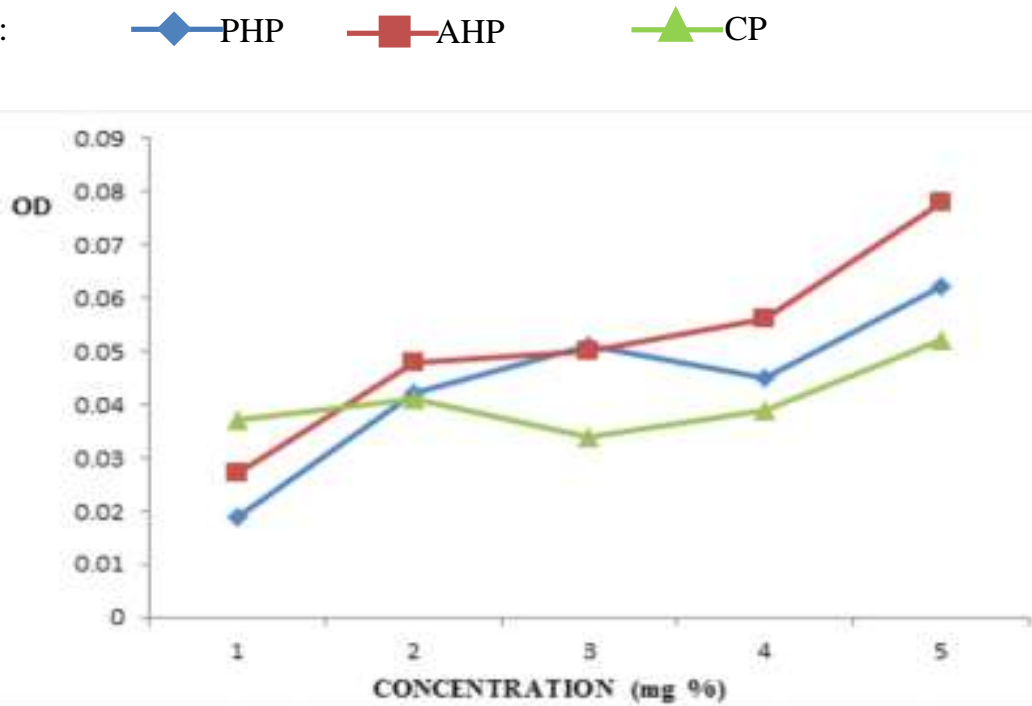
incubation

Fig. 7: Growth of Candida albicans in varied concentration of PAH and CP at 24 hours of

Key:

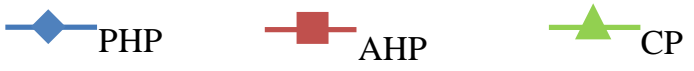




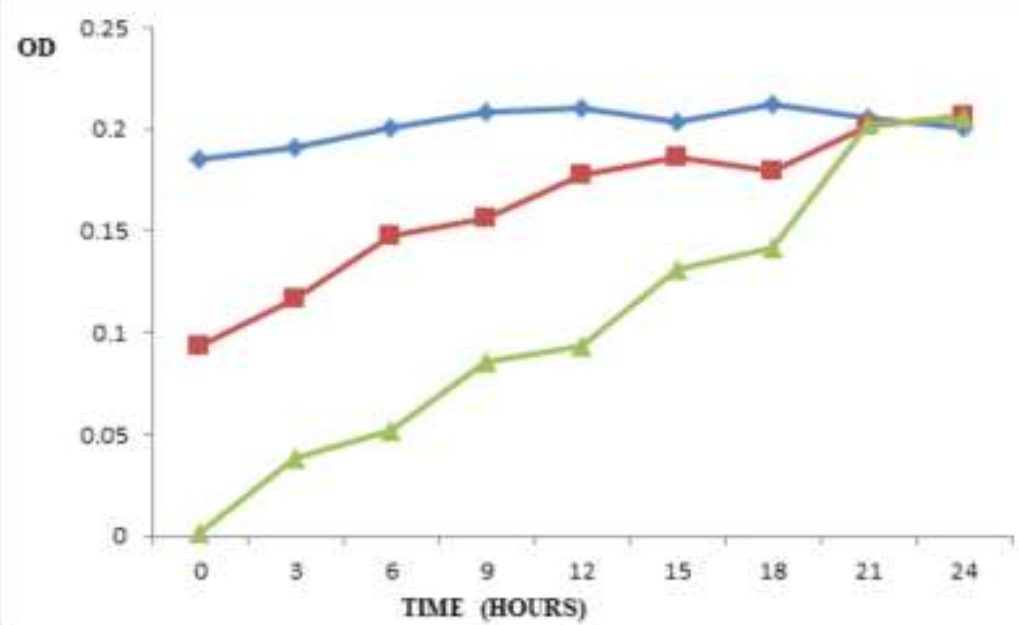
$\mathrm{CP}$

Fig. 8: Growth curve of Candida albicans in $4 \mathrm{mg} \%$ concentration of PHP, AHP or Key:

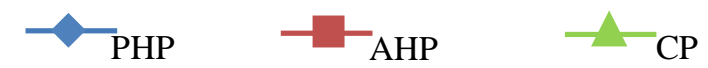

$O D$

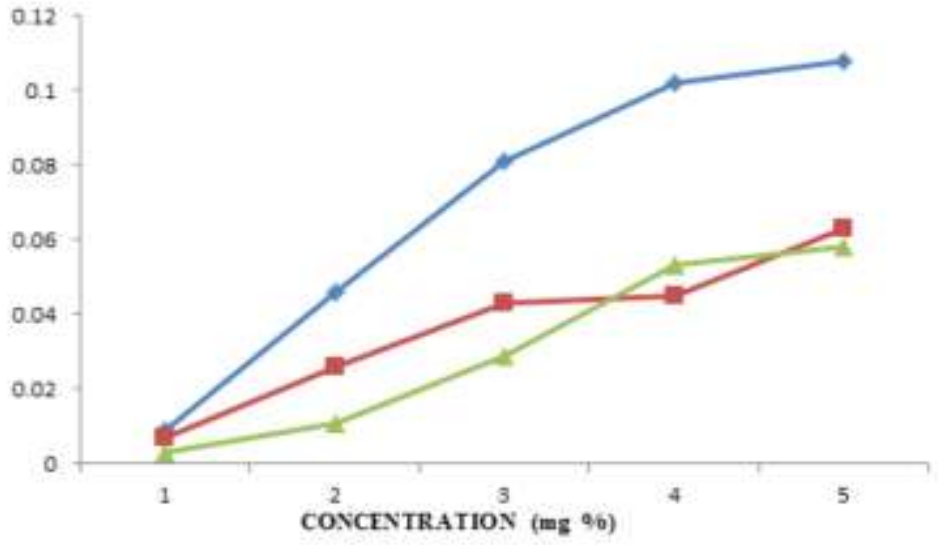

Fig. 9: Growth of Aspergillusniger in $\mathrm{PAH}$ and $\mathrm{CP}$ at 72 hours of incubation

Key:
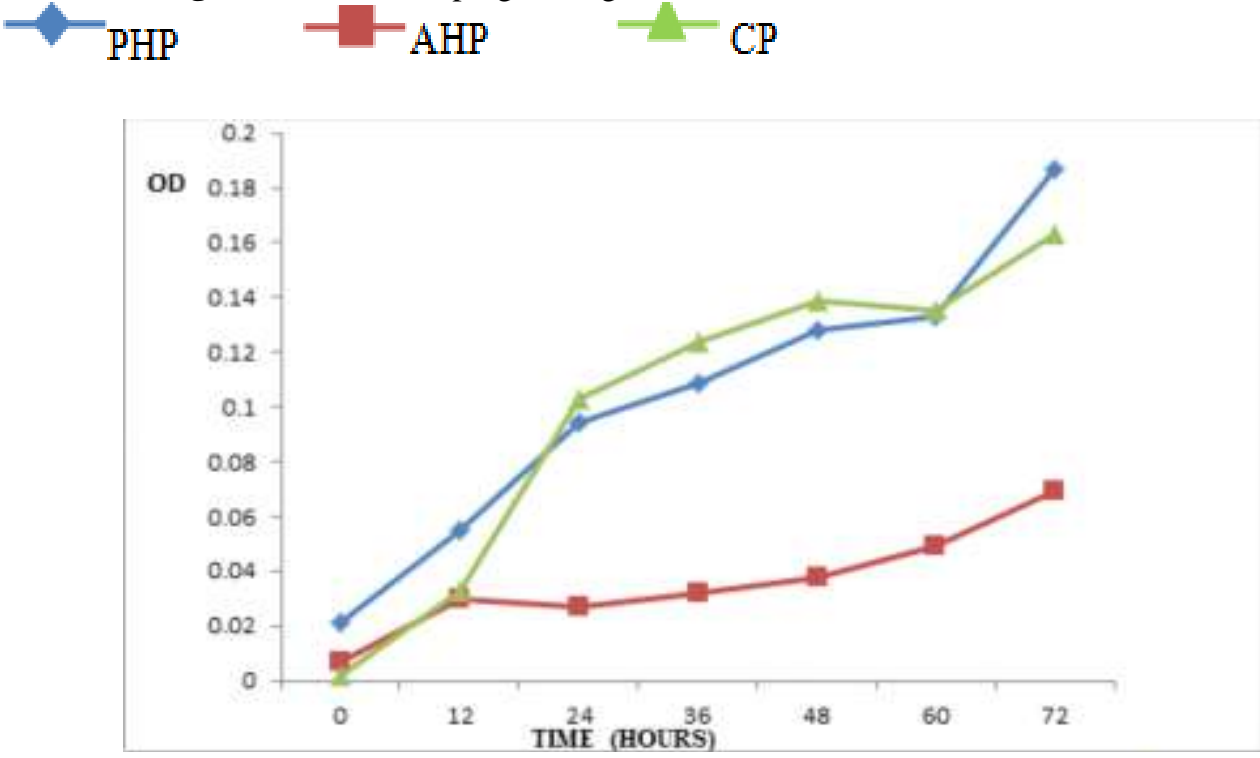

or CP

Fig. 10: Growth curve of Aspergillusnigerin $4 \mathrm{mg} \%$ concentration of PHP, AHP

Key:

$\neg{ }_{\text {PHP }}-{ }_{\mathrm{AHP}} \quad-{ }_{\mathrm{CP}}$




\section{Discussion}

Fig. 1 shows the growth of $S$. aureus in the various media tested. It is apparent that microbial growths in the media were concentration dependent. However, media prepared with PHP or AHP were found to produce better growth of the organisms than media made with $\mathrm{CP}$ after a cumulative incubation period of 24 hours. In addition, when the growth of $S$. aureus was monitored at regular time intervals, there was no significant difference in the growth rate pattern due to the various media (Fig. 2). Similar results were obtained for other bacteria strains (Figs. 3-6), with only slight variations. In specifically comparing the effectiveness of the two test hydrolysates (PHP and AHP), it was noticed that in most situations, the degree of growth support produced by AHP was less than that caused by PHP. Comparable findings have been recorded in other related studies. In a study for the development of fish peptone as nitrogen source for Staphylococcus aureus, it was observed that the mode of hydrolysis has considerable effects on the performance of the resulting peptone[15]. Enhanced activity associated with peptones produced by enzymatic hydrolysis can be explained by the fact that enzymatic hydrolysis is largely complementary to bacterial peptide uptake [16]. The relatively lower level performance of the AHP in supporting bacterial growth may also be due to extensive breakdown of proteins and peptides into component amino acids in the process of acid hydrolysis.

The nutritional requirements of microbial species may also affect their growth response in various media. It appears that concentrate of a hydrolysate in the medium influences bacterial growth rate. Concentration of ram horn hydrolysate beyond an optimum level produced an inhibitory effect on microbial growth [17]. It is known that certain procedures, such as overheating of media during autoclaving, can yield toxic oxygen species [18]. Additionally, storage condition and age of media constituents are known to influence medium performance.

The amino acid composition of microbial growth media is a clearly dominant factor in the performance of the medium [19]. Table 1 represents the amino acids of $P$. africana seeds as determined by either acid or enzyme hydrolysis. The presence of branched-chain amino acids such as leucine, valine and isoleucine, are essential for the growth of the test organisms [20]. Such other micronutrients-vitamins and minerals (Tables 2 and 3) present in the hydrolysates have also contributed to the observed growth pattern of the organisms.

It is noteworthy that the $P$. africana hydrolysates also supported the growth of Candida albicans (yeast) and Aspergillusniger (fungus) in equally concentration-dependent manners (Figs. 7-9). In all cases the effects were comparable with the commercial peptone. Similar reports have been recorded elsewhere, using a variety of other materials as sources of peptone for microbial growth [21-23] There is therefore, overwhelming evidence that alternative sources of peptone, from non-animal sources, are abundantly available, and such great potentials lie also in the seed hydrolysate of P. africana.

\section{Conclusion}

Results from this study have shown that peptone derived from Prosopis africana seed hydrolysates, can compare favourably with commercially available peptone for supporting the growth of test organisms. It is our submission that proper manipulations of in vitro enzyme hydrolysis will result in high grade peptones rich in peptides and polypeptides, which can further be hydrolysed by microbial enzymes for better growth effect. Acid hydrolysis breaks down proteins into their component amino acids and, being a harsh process, some amino acids are lost and salt formation is also inevitable. Prosopis africana seed hydrolysates have, therefore, added to the number of leguminous peptones available for use in microbial media. This product can be used in enrichment media or as a basic nutrient medium. In consideration of the impressive way in which it has supported the growth of the test organisms, it is believed that the production of this peptone will serve as alternative source of peptone, for growth of a wide variety of microorganisms, including bacteria, yeast and fungi.

The authors report no conflicts of interest in the work.

\section{Declaration of interest}

\section{References}

[1]. Agboola DA. Prosopis africana (Mimosaceae): Stem, root and seeds in the economy of the savanna areas of Nigeria. J. Econ Bot. (2005); 58:S34-S42

[2]. Adenike AO, Ogunshe MO, Ayansina ADV. Micro-organisms associated with natural fermentation of Prosopis africana seeds for the production of okpeye. Park JournalNutr(2007); 6: 620-627.

[3]. Baker FJ, Sliverton RE, Pallister, CJ. Microbiological Techniques:Introduction to Medical Laboratory Nigeria Edition. WB Saunder(2001):317-319.

[4]. Hurst CJ, Knudsen GR, McInerney M, Stetzenbach L, Walter MV. Manual of Environmental Microbiology. American Society for Microbiology Press, USA.(1997).

[5]. Green JH,Paskell SL, Goldsmintz D. Fish peptones for microbial media developed from red lake and fishery by-products. J Food Protect(1996); 40:181-186.

[6]. AspomSI, Horn SJ, Ejisink KGH. Use of hydrolysates from Atlantic cod (Gus morhua L.)Viscera as a complex nitrogen source for lactic acid bacteria. FEMS MicrobLett(2005); 248:65-68. 
[7]. Safari R, Motamedzadegen A, Ovissipour M, Regenstein JM, Gildberg A, Rasco B. Use of hydrolysates from yellow fin tuna (Thunnusalbacares) heads as a complex nitrogen source for lactic acid bacteria. Food Bioprocess Chem(2009); 115:238-242.

[8]. Uzeh RE, Akinola SO, Olatope. Production of peptone from soybeans (Glycine Max L merr) and African locust beans (Parkiabiglobosa). Afr J Biotech(2006); 5(18): 1684-1686.

[9]. Pearson, D. Laboratory techniques in food analysis. Butterworth and Co. Ltd. 1976.

[10]. Association of Official and Vitamins Chemist. Official method of analysis: A.O.V.C. Washington D.C, USA. (2005).

[11]. Association of Official and Analytical Chemist. Official method of analysis:A.O.A.C. Washington D.C, USA. (2010).

[12]. Jakutowicz K., Tomic ZI and Leokadia L. Determination of total plasma tocopherol in the presence of carotenes. Pol Arch Water(1997); 20: 45-57.

[13]. Onwuka GI. Food analysis and instrumentation; theory and practice. NaphtaliPrince, Nigeria.(2005).

[14]. Association of Official and Analytical Chemist. Official method of analysis:A.O.A.C. Washington D.C. USA. (1995).

[15]. Fallah M, Bahram S, Javadian SR. Fish peptone development using enzymatic hydrolysis of sliver carp by-products as a nitrogen source in Staphylococcus aureus media. J Food Sci.Nutri(2015); 3(2): 153-157.

[16]. Safari R, Motamedzadegen A, Ovissipour M, Regenstein JM, Gildberg A, Rasco B. Use of hydrolysates from yellow fin tuna (Thunnusalbacares) heads as a complex nitrogen source for lactic acid bacteria. Food Bioprocess Chem(2009); 115:238-242.

[17]. Kurbanoglu EB, Algur OF. Use of peptone ram horn as peptone source for microbial growth. Turk J.Biol(2001); 26:115-123.

[18]. Mackey BM, Derrick CM. Peroxide sensitivity of cold-shocked Salmonellatyphimurium and E. coli and its relationship to minimal medium recovery. J ApplBacteriol(1986); 60: 501-511.

[19]. Sahar FD, GomaaFE, Sawsan AA, Ashraf AK. Autohydrolysed Tilapia nilotica fish viscera as a peptone source in bacteriocin production. Ind JMicrobiol(2011); 51(2): 171-175.

[20]. Taskin M, Kurbanoglu EB. Evaluation of waste chicken feathers as peptone source for microbial growth. J ApplBiol(2011); 111:826-834.

[21]. Guerard F, Duffose L, De La Broise D, Binet A. Enzymatic hydrolysis of protein from yellow fin tuna (Thunnusalbacares) waste using alcalase. JMolCatal B Enzyme(2001); 11: 1051-1059.

[22]. Aspom SI, Horn SJ, Ejisink VG. Hydrolysates from Atlantic cod (Gadusmorhua L) viscera as a component of microbial growth media. Process Biochem(2005); 40:3714-372.

[23]. Nurdiyana H, SitiMazlina, MK, Ling TC, Nurul FM, Norhani J. Comparison of microbial growth on fish waste peptone from different hydrolysis methods. International Conference in Biomedical Engineering and Technology (2015); 1.8:54-57. 